$\left[\begin{array}{lllllllll}M & A & T & E & R & I & A & £ & Y \\ M & A & T & E & R & I & A & L & S\end{array}\right]$

JUSTYNA B. WALKOWIAK

DOI: http://dx.doi.org/10.17651/ONOMAST.64.16

Onomastica LXIV, 2020

https://orcid.org/0000-0001-7301-4591

PL ISSN 0078-4648

justwalk@amu.edu.pl

Uniwersytet im. Adama Mickiewicza

Poznań, Polska

\title{
WSPÓŁCZESNE NAZWISKA POLAKÓW \\ O MOŻLIWEJ GENEZIE LITEWSKIEJ NIEOBECNE W LPŽ, POŚWIADCZONE W KARTOTECE ANTROPONIMICZNEJ LKI
}

Słow a tematyczne: polskie nazwiska, nazwiska pochodzenia litewskiego, etymologiczno-motywacyjny słownik nazwisk, kartoteka, Instytut Języka Litewskiego

Niniejszy artykuł odwołuje się do szerszego opracowania (Walkowiak, 2019) współczesnych nazwisk polskich o genezie litewskiej (tj. o rdzeniu i/lub formancie litewskim), stanowiących ok. 2\% spośród co najmniej 400 tys. nazwisk używanych współcześnie w Polsce (por. Rymut, 1999: vi). Stanowi jego uzupełnienie, wzbogacając go o poświadczenia nazwisk polskich podejrzewanych o litewską genezę, których nie udało się znaleźć w dwutomowym słowniku nazwisk litewskich „Lietuvių pavardžių žodynas” (LPŽ). Pomimo czasu, jaki upłynął od publikacji tego słownika, jest on do dziś podstawowym źródłem, które pomaga wykazać bądź przynajmniej uprawdopodobnić litewską genezę nazwisk, podobnie jak jego nieco uzupełniona postać elektroniczna (LPŽe $)^{1}$ oraz nieomal z nią tożsama litewska baza nazwisk „Pavardžių duomenų bazè”2 (dalej PDB).

Przedstawione zarówno $\mathrm{w}$ ww. opracowaniu, jak i w niniejszym artykule nazwiska stanowią zatem z jednej strony uzupełnienie LPŽ, a z drugiej poprzez obecność w materiale historycznym form polskich z sufiksem -ski oraz żeńskich na -owa, -ówna - także swoiste uzupełnienie „Antroponimii Polski” (por. Cieślikowa, 2007-2016), w której Kresy północne są słabo reprezentowane, oraz poświęconej wyłącznie Kresom pracy L. Dacewicz (2014).

\footnotetext{
${ }^{1} \mathrm{http}: / /$ pavardes.lki.lt/

${ }^{2} \mathrm{http} / / /$ kiis.lki.lt/pavardziu-duomenu-baze
} 
LPŽ dotyczy XX w., jednak ma sporo luk, gdyż dane, na podstawie których go opracowano ${ }^{3}$, zbierano poprzez badania terenowe głównie na obszarze przedwojennej Republiki Litewskiej (Vanagas, 1976, 1994), badania terenowe nie objęły natomiast obszarów należących przed wojną do Polski (polsko-litewskie stosunki dyplomatyczne zostały nawiązane dopiero w roku 1938). Po wojnie te dane uzupełniano o nazwiska z przyłączonej do LSRR Wileńszczyzny, ale zapewne nie uwzględniono nazwisk Polaków przesiedlonych do Polski w latach 1944-1945 oraz 1957-1959 — łącznie blisko 200 tys. osób (Hryciuk, 2008, s. 85, 99), zaś przy uzupełnieniach dotyczących Kłajpedy i Wileńszczyzny posiłkowano się w znacznej mierze dokumentami (LPŽ I, s. 32). Ponadto, co podkreśla D. Mikulènienè (2012), „,w bardzo szczegółowym słowniku nazwisk litewskich (Lietuvių pavardžių žodynas) nie zostały zarejestrowane nazwy osobowe, które zachowały się w archiwum Karłowicza"4 ${ }^{\prime 4} Z$ tych wszystkich powodów LPŽ jest dla badacza nazwisk polskich pochodzenia litewskiego źródłem oczywiście fundamentalnym, ale w niektórych konkretnych przypadkach niewystarczającym, gdyż we współczesnym onomastykonie polskim istnieją nienotowane w LPŽ nazwiska, w wypadku których można zasadnie podejrzewać genezę litewską.

Dlatego cennym wsparciem w takich badaniach — i uzupełnieniem danych zawartych we wspomnianym opracowaniu (Walkowiak, 2019) — może być kartoteka nazw osobowych wyekscerpowanych z rękopiśmiennych i drukowanych źródeł historycznych z XVI-XIX w. (ok. 200 tys. papierowych fiszek ${ }^{5}$ ) gromadzona od kilku dekad w Instytucie Języka Litewskiego (LKI) w Wilnie. Sama lista tych źródeł — wśród których przeważają księgi metrykalne — jest pokaźna, wypełnia oddzielny segregator kartoteki. Pojedyncza fiszka zawiera nazwisko (bądź antroponim o charakterze protonazwiska) w oryginalnym zapisie źródła (cyrylica, ligatury, dawne diakrytyki itp.), często też towarzyszy mu imię, z reguły także miejsce oraz rok lub dość wąski przedział czasowy poświadczenia (co jest szczególnie typowe dla ksiąg metrykalnych). W przypadku danych metrykalnych charakterystyczna jest też informacja o charakterze, w jakim referent danego antroponimu występuje (np. matka chrzestna, świadek). Często na fiszce znajduje się również nazwisko pracownika LKI, który dokonał ekscerpcji. Na to, że ekscerpcji dokonywało kilka różnych osób, wskazują rozmaite charaktery pisma, ponadto część fiszek jest w całości sporządzona ręcznie, a część drukowana z miejscami do uzupełnienia.

${ }^{3}$ W wyniku tych badań powstało 260 tys. fiszek, do dziś przechowywanych w LKI (por. http:// 1ki.lt/baltu-kalbu-ir-vardyno-tyrimu-centras/\#1494772804079-a2f4cc40-9786).

${ }^{4}$ Jan Karłowicz (1836-1903), badacz o wielorakich zainteresowaniach naukowych (m.in. językoznawstwo i etnografia), pozostawił po sobie w znacznej mierze niewykorzystane badawczo zbiory antroponimii litewskiej, obecnie przechowywane w Litewskim Państwowym Archiwum Historycznym (F1135|10), zob. Mikulènienè, 2012.

${ }^{5}$ http://lki.lt/baltu-kalbu-ir-vardyno-tyrimu-centras/\#1494772804079-a2f4cc40-9786 
Przeprowadzona kwerenda ${ }^{6}$ miała na celu potwierdzenie bądź przynajmniej uprawdopodobnienie litewskiej (czy, szerzej, bałtyckiej — często trudno to jednoznacznie rozgraniczyć, por. Kondratiuk, 2000) genezy nazwisk nieobecnych w LPŽ, lecz mimo to z istotnych przyczyn włączonych do wspomnianego wyżej opracowania. Takimi czynnikami mogły być: charakterystyczna budowa morfologiczna nazwiska, jego występowanie w innych opracowaniach antroponimii litewskiej/bałtyckiej, istnienie odpowiednika we współczesnej antroponimii litewskiej czy ewentualnie łotewskiej, dodatkowo też ważny był współczesny rozkład geograficzny w Polsce. Warto mieć na uwadze, że omawiany materiał trudno poddaje się jednoznacznej interpretacji lingwistyczno-kulturowej, a zaproponowane etymologie są niejednokrotnie hipotezami.

W wyniku kwerendy znaleziono dwojakiego rodzaju poświadczenia: bezpośrednie i pośrednie. Przykładowo forma Auk J̧latis stanowi bezpośrednie poświadczenie litewskiego pochodzenia dla współczesnego nazwiska Aukschlat), natomiast forma Alsutaytis pośrednio poświadcza niegdysiejszą obecność antroponimu Alsut, od którego jest sufiksalnie derywowana. W dalszej części tekstu, ze względu na szczupłość miejsca, skupiono się głównie na nazwiskach poświadczonych bezpośrednio.

Jedną z cech właściwej badanemu okresowi (do XIX w. włącznie) wariantywności morfologicznej nazw osobowych (często już o statusie nazwisk) jest równoległe istnienie form o końcówce litewskiej oraz spolonizowanych (z polskimi sufiksami -ski, -cki, -owicz oraz żeńskimi -owa, -owna), nierzadko zapewne w odniesieniu do tej samej osoby. Sufiksalne formy polskie tworzono zarówno od litewskich rdzeni (apelatywnych, imion litewskich oraz litewskich postaci imion chrześcijańskich), jak i od spolszczonych bałtyckich nazw miejscowych — w ostatnim wypadku pierwiastek litewski występuje w apelatywie fundującym taką nazwę.

Poświadczenia uszeregowano według podobieństwa morfologicznego do formy, dla której stanowią potencjalne poświadczenie. W nawiasach okrągłych umieszczono dopiski ekscerpujących znajdujące się na fiszce, w kwadratowych uwagi autorskie. W wypadku wątpliwości co do postaci mianownika nazwy miejscowej pozostawiano ją we właściwym językowi litewskiemu dopełniaczu, opatrując dopiskiem [dop.]. Rozwiązania skrótów odnoszących się do nazw miejscowych oraz do typów ksiąg metrykalnych znajdują się na końcu artykułu.

ALKA, ALKE (prus. n. o. Alke, Trautmann, 1974, s. 12): Alkowna 1666 Pun — choć możliwe też pochodzenie od poświadczonego w LPŽ *Alkas (of. Alk).

${ }^{6}$ Badanie finansowane z grantu NCN 2018/02/X/HS2/02008. Okres realizacji projektu: 2019_ 2020. Autorka składa niniejszym podziękowanie p. dr Albinie Auksoriūtè, dyr. Instytutu Języka Litewskiego (Lietuvių kalbos institutas, LKI), za zgodę na publikację danych, p. prof. Grasildzie Blažienè za zaproszenie na kwerendę oraz pracownikom LKI za konsultacje. 
AUKSCHLAT (*Aukšlaitis, por. lit. aukšlas, aukšlys 'kobiałka'): Auk/ろlas, Auk/ろlatis 1769-1864 Rag; Aukszla 1609 par. Ukm, dw. Panemunis; AukJzle 1769-1822 Rag.

AUSZTOL: Aufztolis 1777 sen. Vlk, w. Dargužiai. Przekonanie M. Kondratiuka (2004, s. 21) o związku z n. Auksztol (<aukštuõlis : áukštas 'wysoki') znajduje potwierdzenie w podobnych uproszczeniach zbitek spółgłoskowych w innych nazwiskach, jak np. Casimirum Ausztakais, Jofepho Aufztakaius, Marianna Aufztakojowa, Petro Aufztokoisz (< lit. n. Aukštakõjis : lit. áukštas 'wysoki', kója 'noga').

BAKSA (prus. n. o. Baxe, Trautmann, 1974, s. 16): Bakks, Baaks 1757-1767 Rag, Baks 17571767, 1769-1822 Rag; Baxys 1795 par. Daugai, Kończany; Evam Baxaicia [f] 1653, Baxis 1655 Lnkl; Baksis 1754 de Janiszki (Jon J); Elisabetha Baksicia 1770 de Kanczuny; Andrzey Baxiewicz $1626 \mathrm{~K}$.

BAŁTUK (lit. baltukas 'bielinek', łac. Pieris): Casimiri Battuc 1694 Ad G; Stanisław Battuk 1702 vls. Kelmès, w. Uzniowkanie; Baltuciowa 1816 Sd; Battukaytie 1658 Krž KR; Battukiewicz 1657, Baltukiewicz 1664 Krž KR; Juzefa [sic] i Zuzanny Anczewkiewiczow Battukiewiczow $1832 \mathrm{Mrc}$ KR.

BARAT (wsp. lit. n. Baraitis < Bãras?): Бopaumuc 1537 vls. Viešvėnai; Boraitys 1637 Lukniu [dop.] mst. [Lukniai? Luknés?]; Baraytis 1657, 1659, 1662 Krž KR.

BIERAGA (lit. n. o. Beragis): Catharinæ Beragiczia 1764-1786 Užp KR.

BILMON (wsp. łot. n. Bīlmanis): Jozef Bilman 1780-1785 K.

BITAN (łot. n. Bitāns, Bitainis): Bitanis de Bitany 1652-1672 Vdn KR; Bitanis 1691-1781 Vdn J; Vilhelmo Byten 1809 Imbr KR; Byteń 1809 Imbr.

BIWAN (< lit. n. złoż. Bìvainis, Bivaĩnis, Bývainis, Byvaĩnis?): Bywan 1729-1776 Ut J; Biwanelis $1652-1672 \mathrm{Vdn} \mathrm{KR}$.

BOLENAJC (<*Bolenaitis?): Bolenaytis 1653 w. Szawkienie [Šaukènai, Szawkiany].

BOŁTUN (wsp. n. lit. Baltunis i ap. bottun/battun 'mieszanina wody z otrębami, grubą mąką razową z dodatkiem drobno posiekanych ziemniaków lub warzyw (karma dla bydła)', Rieger, 1996, s. 84): Baltun, Catharina Baltuniczia, Anna Battunienia 1729-1771 Ut KR; Baltunowna 17291776 Ut J; Valentij Baltunia 1694 vls. Krt, zaścianek Lygnugarių [dop.]; Antoni Battunia 1767 Krt, w. Vèlaičiai; Józef Battunis 1755 r. Krtn, w. Vaineikiai.

BOŁZAN (wsp. lit. n. Bolzanas): Sophia Botzanka 1681 Paparčiai KR.

BOMBLIS (< lit. n. Bumblỹs? Por. też lit. bamblỹs 'rozpieszczone, rozpuszczone dziecko; dziecko lub dorosły z dużym brzuchem; papla, pleciuch; płaksa, mazgaj, beksa'): Bomblis 1659, 1661, 1662, 1663, 1664, 1667, 1669 Ad G; Bomblis 1662 vls. Krk, w. Pokorkle; Casimirus Bablis 1699 Ad G; Bomblis 1800, 1810 Ad M; Catherina Bomblowa 1661 Ad G; Johanna Bomblowna 1807 par. Kl KR; Криштофь Бам’блайтис 1650 Akm.

BORGULAT (<*Bargulaitis? Por. lit. n. Bargáila, Bargelis): Cristinam Bargiułowna 1681 Lnkl J.

BRAZGALSKI (lit. brazgùliai 'dzwonki, dzwoneczki, zwłaszcza kilka małych dzwoneczków przymocowanych do chomąta', brazguli/brazguny, w gwarze wileńskiej 'metalowe brzękadła na uprzęży końskiej, janczary lub dzwoneczki u szyi bydła'; por. wsp. lit. n. Brazgulis, Rieger, 1996, s. 84, SPG 82, 149-150): Brazgis 1637 vls. Als, w. Wilkaicie.

BROLNICKI (lit. brólis 'brat'): Dorothea Brolnicka 1680, Cafper Brolnicki 1684 Paparčiai KR.

BUJWICKI (n. m. Bujwidze, lit. Buivydžiai, i Bujwidy, lit. Buivydai, oba od lit. n. o. Bùivydas, Buivydas, Buividas): Buywickas 1729-1776 Ut J; Agatha Buywicka 1760 Kieydany KR.

BUMBIERYS (wsp. lit. n. Bimberis, łot. n. Bumberis, Bumbieris): Tomasz Bumber 1795 Varèna.

BUSE (prus. n. o. Buse, Busse, Buze, Trautmann, 1974, s. 21; jednak prus. n. o. Bawse ma zapewne inną genezę, por. Ivoška, 2018, s. 56, 68): Буссе, Людовика Людомировна 1882 vls. Жидыковская.

BUTRYN (wsp. lit. n. Butrinas): Casimiri Butrin 1701 Noč KR; Tomasz Butrynaytis II poł. XVI w., aps. Rt, w. Wilki; Petri Butris 1693 Ad G.

CIWIEL (lit. n. Civilis < Čivilis, Čivỹlis < lit. čivỹlis 'makolągwa'): Catharina Ciwielanka, Barbara Ciwilenia, Ciwilis [5 poświadczeń] 1652-1672 Vdn KR; Ciwilis [6 poświadczeń] 1691-1781 Vdn J. 
CYLWIŃSKI (wsp. lit. n. Tilvinas, może związek z lit. tilvikas 'ptak z rodziny bekasowatych, kulik'): Jan Cilwin 1790 Upyna.

CZEKIEŃ (wsp. lit. n. Čekenis): Samuel Czekonis 1642 Švnč par. G; Adam Ciekienas 1655 par. Troki, dw. Alešiškès, w. Lelance; Catharina Czekienia 1729-1771 Ut KR.

CZEPOLONIS (wsp. lit. n. Čepalionis, Čepolionis): Anna Czepolanowa, Anna Czepolowna 16781693 Užp KR; Casimiri et Catherinae Czepatenow, Catherina Czepalenowa 1729-1771 Ut KR.

CZYŻELSKI (<*Čiželis < Čižas?): Czyzelis, Czyżelis 1678-1693 Užp KR; Czyzel Dgl KR; Michaelis Czyzela 1729-1771 Ut KR; Czyżelowna 1759-1787 Krns KR.

ĆWIRBUT (lit. n. o. Tvirbutas < lit. tvérti 'tworzyć, zakładać', tvirtas 'silny', bùtti 'być', būtìs 'byt, istnienie'): Cwirbutowicz 1676 Lnkl.

DAGIL (prus. n. o. Dagil (Trautmann, 1974, s. 22), ale też lit. n. Dagìlis, Dagilỹs, Dagilius < lit. dagìlis 'oset; rzep, np. łopianu; ostrożeń (roślina, łac. Cirsium); szczygieł (łac. Carduelis carduelis)'): Kazimierza Dagila [dop.] 1771-1773 K.

DAJNA, DOJNIA, DAJNOWSKI (lit. n. o. Dainỹs, Daĩnius, lit. daina 'pieśń', dainỹs, daĩnius 'śpiewak, piewca'): Doyniskis 1561 vls. Jurbarkas, w. Doynie; Doinis 1610 Ukm, dw. Deltuva; Doynis 1616 par. Ašmena, dw. Geranainys-Subatninkai, w. Gierdziuny; Dorotha Dayniowna 1643 Švnč G; Doynowski/Doynowska 1665, 1666, 1667, 1680 Paparčiai KR; Helena Dayniowa 1669 Krž; Daynicie de Daynie 1678-1691 Krns KR; Doynorowicz, Anna Doÿnarowiczowna, Doynowski 1685-1731 Dgl KR; Mathia Daynis 1759, Mathia Daynie 1763 Buczuny (Kdn KR); Daynawski 1830 Srj.

DEPKUN (<Dapkūnas? Dabkūnas < Dãbkus? — geneza niejasna, być może słowiańska): Martinus Depkunas, Lucia Depkiniowa 1690 Ad G; Georgius Depkinas 1691-1781 Vdn J; Stas, Marek Depkaycie II poł. XVI w., aps. Rt, w. Sprawdzie; Depkowski Ut KR 1729-1771.

DIETRICHKEIT (niem. n. o. Dittrich, Dietrich ze skróconym lit. sufiksem patronimicznym -aitis): Didrikacze 1757-1767 Rag.

DIEWS (rdzeń diev- jak w lit. Dievas 'Bóg'): Martini et Annae Dieus [Dievs?] 1729-1771 Ut KR.

DOGWIŁŁO (<*lit. n. o. złoż. Daũgvilas, Dòvgvilas, Daugvilà < lit. daũg 'dużo, wiele, wielu’, viltìs 'nadzieja'): Dagwitaitis, Daugwiłaitis, Zophia Daugwitaicia 1600 Jon (por. też Ragauskaite, 2019, s. 180 - Daugwitaitis 1602 Jon); Joannes Dowgwit 1727, Anna Dowgwilenia 1726 Dt KR; Довгвилло 1882 Красносельская в., Сурвилишская в., Кракиновская в.; Daugwil 1637 mst. Krk; Paweł Parobek Daugwiłaicia 1662 vls. Krk, w. Pokorkle; Daugwit 1695 par. Dt J; Daugwilas 1695, Daugwiłaytis 1705, Joanes Daugwiłowicz 1726 Dt KR.

DOWGAJŁO (d. lit. im. męskie Daugáila i n. Dowgiałto < Daugèla, Daugela, por. też Dowgiało 1693 K (Ragauskaite, 2005, s. 132)): Лютко Довкгайловичъ 1528 Veliuona; Мицъ Довкгайловичъ 1528 Žr; Dowgal 1705 Noč KR; Dowgała 1732 K J.

DOWGUN (od imion skróconych na Daũg- < lit. daũg 'dużo, wiele, wielu’ — por. Sinkevičiūtè, 2006, s. 119, Zinkevičius, 2008, s. 199): Christophorum Daugunis de Auguny 1691-1781 Vdn J.

DRUCIS (lit. n. Drütỹs): Drucis 1653 Lnkl J; Drucius 1693 Skaruliai.

DULGIS (łot. n. m. Dulgis, bagno w Kurlandii na Łotwie): Catharina Duelgiowa 1747 Grz M.

DUMALEWSKI (prus. n. m. Dumele < prus. dumis 'dym', lit. dūmẽlis 'dymek, mgiełka'): Kazimierz Dumelis, Stanisław Dumelis 1637 mst. Als; Michał Dumelis 1662 mst. Varn, w. Połukscie; Stanisława Dumelia 1662 mst. Varn; Magdalena Dumelowna 1669 Krž.

DYKANIEC (*Dikonis $<$ Dikas $<$ pol. dzik lub niem. Dick, Dieck czy Dykinis < lit. dykìnis 'leń, wałkoń, próżniak'?): Dikinis, Dikiniowa 1685-1731 Dgl J; Dikinis, Dikynis, Dykinis, Dikinowna, Dykanowna 1729-1771 Ut KR; Dikys 1640, Dikis 1645, Dykis 1684 Grz J.

DYRSOWICZ (< lit. dirse 'stokłosa, łac. Bromus'): Dyrsewicz 1759-1787 Krns KR.

DZIADEL (<Dédẽlis? < Dédẽle < lit. déde 'wujek, stryjek; każdy starszy mężczyzna'): dom Macieia Dziedelia 1609 V; Thomaßa Dziedela 1628 V; Ioanne Dziedelonis 1640 Švnč G, Joannem Diedelonis 1647 Lnkl J; Christophorus Dziedalis 1680 Paparčiai KR; Catharina Dziedełowa 1689 Ad G; Georgij Dziedelan 1690 Ad G. Na rozchwianie ortograficzne, zapewne odzwierciedlające rozbieżności artykulacyjne samogłosek $e, a$ wskazują równoczesne poświadczenia Dziedonis 1643, 1644 i Dziadonis 1642, oba Švnč G. 
DZIEWGUĆ (wsp. lit. n. Devgutis): Dziewgiecz 1602-1615 V; Dziauguc 1655, 1680, 1698 Ad G; Dziawgocki 1655 Ad G; Joannis Dzieuga 1657 Ad G; Martini Dziauga 1659 Ad G; Dziauguc 1670 Ad G; Dziawguc 1698 Ad G.

EITEL (< prus. n. o. Eytil, Eytel, Trautmann, 1974, s. 27, lub ew. niem. eitel 'zarozumiały, nadęty'): Богдан Еитилович 1542 Šln; Catharina Eytelkowna, Lucia Eyteluszkowna 1729-1776 Ut J.

GERUSCHKAT (<*Geruškaitis?): Juchno Gierusowicz 1554 dw. [Raudondvaris] Nemenčinè (Niemenczyn); Gieruska [f] 1759-1787 Krns KR.

GEŻYŃSKI (wsp. lit. n. Gežinis < Gežỹys): Michał Gielzynis 1694 vls. Krt, w. Bučniai; Gietzynis, Gielzynis 1711 Krt; Gielzynis 1767 Krt graf., w. Bučniai; Marcianna Gieżyniowa (kr. mot.) 1802 par. Krt — jedyne poświadczenie bez litery „,”; Marianna Gielzynowa (kr. mot.) 1804 par. Krt [jeśli ta sama co powyżej, to by sugerowało, że jest to zniekształcone n. Gelžinis < gelžinis, geležinis ‘żelazny'].

GIEREJKO (< lit. n. Geraitis?): Staniflawowi Giereykowi 1625 K.

GIERUKAS (< lit. geras 'dobry'): Jacobus Gerukas 1729-1771 Ut KR.

GIEWIEL (wsp. łot. n. Ģēvelis, Gēvelis, Gevelis, lit. gèvelis, gèvelỹs 'szczyt dachu; chudy człowiek lub zwierzę; człowiek słabego zdrowia; głupek, gamoń, gapa'): Christina Giewelowa 1678-1691 Krns KR; Simon Giewialis, Christina Giewiatowa, Cristina Giewielenie 17401760 Link KR; Criftina Giewielowna 1760-90 Link KR; Anna Gewilowna 1658, 1659 Krž; Stanislai Giewilis 1658 Krž.

GIEZGAŁA (< lit. n. o. Gezgailas, Kęzgaila, Kęzgailas, Kęzgilas? Zinkevičius, 2008, s. 205, 212): Jurgis Kiezgił 1695 Paj, dw. Švejkšna, woyt. Awgilowe [rozchwianie k, $g$ - por. n. Gežỹs, pot. Kežỹs (LPŽ I, s. 662)].

GIRGEL (wsp. lit. n. Girgelis): Woyta Girgiela 1616 Jon; Terefsa Giergetiowna (?) [dopisek LKI] 1701 Noč KR.

GIRSA (pol. gw. girsa < lit. girsè, girsa, dirsè, dirsa 'stokłosa, łac. Bromus'): Casimirus Girsa $1729-1776$ Ut J.

GIRYS (lit. n. o. Gìris < lit. gìrti(s) 'chwalić (się)' lub lit. dial. gìrti 'pić'; Zinkevičius, 2008, s. 94, 283): Giris 1759-1787 Krns KR.

GIWOJNO (lit. n. o. Gývainas, Zinkevičius, 2008, s. 613): Jerźy Giwoyna 1743, Stanisław Giwoyna 1759, 1763 Ps v., w. Pasvaliečiai.

GORGEL (lit. gõrgelis 'pijak’ lub gargãlis ‘beksa; ktoś, kto chrapie; ktoś, kto krzyczy ochrypłym głosem'): Stanislaw Gargiel 1782 w. Sarginie, sen. Prienai [Preny]; Gargiełaytis 1686 Pun.

GRAUŻLIS (wsp. lit. n. Graužlys, lit. graũžlas, graužlỹs 'ogryzek; zeschnięta kromka chleba'): Ignatius Grawzlis 1804 par. Kl.

GRECZAN (< lit. grečionis ‘Greczyn, Grek’?): Marta Greczanis 1875 Krsn; Greczius 1691-1781 Vdn J; Greczys 1708-1740 Link KR; Basilius greckian [sic] 1680, Martini Greckien 1694 Ad G; Matthei Greckienas 1691 Ad G; Marianna Greckienie 1695 Ad G; Marianna Greckiena 1698 Ad G.

GRODEL (wsp. lit. n. Grodelis): Grodelis de Grodzie 1652-1672 Vdn KR [kilka poświadczeń]; Grodelis 1678-1693 Užp KR; Grodelis 1685-1731 Dgl KR, J [kilka poświadczeń].

GRUSZTEL (< lit. n. Grūšttà, Grùštas, Grǔžtas < lit. grūžtìs, grúǔztis 'bóle brzucha; kolka niemowlęca; bóle serca; żal, zmartwienie'): Martinum Grusztełaitis 1664 Vlkv r., Lnkl J; Annam Grufztelowna 1691-1781 Vdn J.

GRYKIEL (wsp. lit. n. Grikelis): Georgÿ Grikiel 1729-1771 Ut KR.

GRYSZKUT (< lit. *Griškutis < Griškus < Griškà < Григорuŭ?): Marinam Gryszkuýcia 1691 Lnkl J. GUDWIŁOWICZ (lit. im. złoż. Gùdvilas, Zinkevičius, 2008, s. 96): Barbara Gudwiłowa 1816 Sd.

GULAN (łot. n. Guḷāns, Gulāns): Annæ de Domo Gułanowna 1807 Imbr KR.

GURGIELEWICZ (< Gurgeláitis < lit. gurglỹs 'ktoś, kto burczy, bulgocze, gulgocze'? Zinkevičius, 2008, s. 579): Ignacy Gurgielewicz z Kowna 1808 (1791-1827 K M).

JAGUCZAŃSKI (prus. n. o. Jagutte, Jagotthe, Jagawde, Trautmann, 1974, s. 38): Elisabetha Jaguczanska 1670 Krž KR; Jaguczanski 1671 K; Ягучанская, Ельвира 1882 vls. Бетигольцкая. 
JAKAĆ ( $<$ Jakáitis < Jãkas ‘Jakub, Joachim’? Ale por. też Jakać, struga w woj. podlaskim, etymologia niejasna, Babik, 2001, s. 137): Agatha Jakaciowna 1813 Švnč M; Stasia Jakajcia [dop.] 1597 vls. Tendžiogala, w. Daužnagiai; Wała Jakaycia [dop.] 1629 V, dw. Nemenčinè [Niemenczyn]; Jakaic 1637 mst. Papile; vls. Papilè, w. Jonaicie; Christinæ [?] Jakä̈cia 1645 Lnkl J.

JAKUBIAŁOJĆ (<*Jokubelaitis < lit. Jãkubas ‘Jakub'): Dawid Jakubełaytys 1695 Paj, dw. Švèksna; Stanisław Jakubelaytis 1695 Paj, dw. Švejksna, woyt. Rawdziowe; Annae Jakubelowna, Jakubetayczia $1808-1820$ Vad KR.

JANCZUKAJTIS (lit. n. Jančiùkas < Jančỹs): Elisabetha Janczukayciowa 1680 Paparčiai KR.

JASIUNIEC (d. lit. n. Jasiunis): Jasiuniec 1803, 1815, 1818, 1820 Int; Angella Jasiuncówna 1821 Int M; Barbarae de domo Jasiuniczia 1729-1771 Ut KR; Andreas Jasiunis 1764-1786 Užp KR.

JAWID (d. lit. n. o. złoż. Jóvydas, Zinkevičius, 2008, s. 72): Franciszek Jawid pleban simnienski [lit. Simnas, pol. Simno] 1782; Jawidis 1729-1776 J, 1729-1771 Ut KR [kilka poświadczeń]; Michàèl Jowidis, Nicolai Jowidis, Adamus Jowidis de Jowidzie, Catharine Jowidaycia, Catharinae Jowidis de Jowidzie, Sophia Jowidziowa de Jowidzie 1678-1691 Krns KR; Ambrozi Jawidanis 1678-1693 Užp KR.

JEŚMAN (lit. n. o. złoż. Jasmanas, Jašmanas i wsp. lit. i łot. n. Jesmanas, Jasmanis): S Piotrem Jesmanem 1598 par. Ukm; Kazimierz Jefmon 1694 vls. Krt, w. Būdviečiai; Casimirus Jesmont 1729-1771 Ut KR; Ewa Jesmonayczia, Laurentius Jesmont, Helena Jesmontowna, Mariannae Jesmanticzia 1764-1786 Užp KR.

JODDA (lit. n. m. Juoda < lit. júodas 'czarny'): Joannes Jodacis de Joda 1652-1672 Vdn KR; Jana Juoda 1662 mst. Varn; Laurentij et Zofiae Joda 1729-1771 Ut KR.

JONAN (< Janónis < Jãnas, Janỹs? Zinkevičius, 2008, s. 366): Jonanis 1630 Lnk1 J, 1640, 1643 Švnč G, 1621-1646, 1685-1731 Dgl J, 1697-1719 Vb J, 1696-1719 Krns J, 1765 St. Łojciewskie, w. Łojcie; 1765 sen. Subačius, w. Piweniszki i Bohdaniszki, aps. Ukm.

JUNAJTYS (<Jonáitis lub Jenáitis? Być może forma gwarowa, por. Zinkevičius, 2008, s. 365-367): Baniul Junaicis 1600 Beržènų vls.; Stanislaus Junaitis 1600 Jon, Laurins Junaitis 1615 Jon; Stephanus Junaytis 1645 Grz J; Symon Junaitys 1750 dw. Klm, w. Šlyžiškè.

KANTEL (prus. n. o. Cantele, Kantele, Cantelyn, Trautmann, 1974, s. 42): Kantel 1690, 1692, $1781-1788 \mathrm{~K}$.

KARNAT (wsp. lit. n. Karnaitis): Tomasz Karnaytis 1619 Vdk, dw. Šln, w. Bodkuni; Antonio Karnas 1691-1781 Vdn J.

KARTUNOWICZ (lit. kartūnis, kartūninis obuolỹs 'gorzkie jabłko’; w polszczyźnie okolic Puńska kartuny, kartunki to 'gorzkie jabłka'): Kartunas 1808-1820 Vad KR.

KARUK (lit. kariukai 'lekki paradny wóz; siedzenie z oparciem na wozie, z resorami; sanie do przewozu belek, kłód', Rieger, 1996, s. 90): Karukas 1729-1771 Ut KR.

KAUKEL (lit. kaukelis 'mandragora lekarska, łac. Mandragora officinarum' lub d. lit. n. o. Kaukẽle $<$ lit. kaukas, kaũkas 'duch domowy, skrzat domowy przynoszący domowi bogactwo; diabeł; starszy człowiek o czerstwej cerze, z rozczochranymi włosami’): Nicolao Kaukelis 1637 Lnkl J; Kaukełaytis 1676 Pun; Kaukelowa, Kaukielowna 1679 Pun; Zophiae Kaukeliciae 1685$1731 \mathrm{Dgl}$ KR.

KAUSZEL (wsp. lit. n. i n. m. Kaušelis < lit. kaušẽlis 'małżowina uszna; daszek od czapki; część kosiarki do siana'): Laurentÿ et Sophiae Kaufzel 1740-1759 Krns KR; Józef Kauszel 1765 St. Kurkleckie, w. Kurklecie; Kaufzelowna, Kauszewicz, Kaufzelis 1759-1787 Krns KR (kilka poświadczeń); Kauszalis 1697 Skaruliai; Kauszalowna 1759-1787 Krns KR, 1729-1771 Ut KR; Stephano Kauszelunas 1656 Lnk1 J.

KIEMEL (lit. kiemelis 'dziedziniec, podwórko' i lit. n. m. Kiemeliai (rejon poswolski) oraz kilka d. n. m.): Simon Kiemel 1553 K; Wawrzyniec Kiemelelis 1784 r. Rk, w. Taraldžiai.

KIERA (może pokrewne lit. n. Kẽras, Kẽras, Kerỹs < lit. kẽras 'obcięty lub złamany pień drzewa ze wszystkimi korzeniami; roślina z pniem i korzeniami; krzew, krzak', keróti, dobrze się rozwijać, rosnąć; rozrastać się, rozgałęziać się', kerùs 'kłótliwy, pyskaty, zaczepny, zadziorny'): Kiera [kilka poświadczeń] 1729-1771 Ut KR, 1729-1776 J; Michał Kiera 1765 vls. Užp, w. Mikuny i Korkoryszki. 
KIERKLA (lit. kerklỹs 'krzykacz’): Urban Kierkła 1637 vls. Varn, w. Kuianie [!]; Воит’кус Кгер 'клорайтис [?] 1537 vls. Karšuva.

KIERUN (etymologia niejasna — p. Kiera): Georgij et Evae Kieruna, Stanislaus Kierunas, Georgius Kierunas/Kierunasz, Eva Kierunowa, Catharina Kierunowa 1729-1771 Ut KR; Zofia Kerunowna $1729-1776$ Ut J.

KIEZA (może od lit. n. o. Kežàa, Kéžas, Kežỹs < lit. kẽžas 'karzeł', Zinkevičius, 2008, s. 557): Kiezaicia 1650 Lnk1 J; Kieziewicz 1695, Kiezewiczowna 1701 par. Dt; Kieziowna 1691-1781 Vdn J; Kieziczie [f], Kiezis 1729-1771 Ut KR.

KIRCIO (lit. n. Kiřčius < kirčius 'drwal, rębacz', por. kirtis 'uderzenie, cios'): Якубъ Кгирча 1584 dw. Laukstinu [dop.]; Staniflaus Kircza 1669 Grz J.

KIRPSZA (wsp. lit. n. Kìrp̌̌a < lit. kìrpša 'człowiek z krótko obciętymi włosami'): Kirpsza 1695 Skaruliai.

KIWERSKI, KIWIEROWICZ (lit. n. Kìveris, Kìvaras, łot. n. Ķivers - może z lit. kìveras 'rodzaj dawnego żołnierskiego nakrycia głowy', kìveris 'dawna wysoka żołnierska czapka', łot. ķivere 'wojskowy hełm; głowa'): Kiwerä̈tis 1637, Kiweraytis 1639 Lnk1 J.

KONTRAT (wsp. lit. n. Kontraitis): Elisabetha Kontratowna 1759-1787 Krns; Якшис Кон 'трайтис 1537 vls. Dirvėnai KR.

KOSPAT (wsp. lit. n. Kaspaitis, Kaspait): Kaspat 1675 Grz J.

KORSZUŃ (<*Karšunis < Kař̌̃̃ys, Keršỹs, Kéršis, Keršas, Kéršius i lit. ap. kéršas, keřšas 'srokaty (o koniu); łaciaty, pstry, pstrokaty, różnokolorowy; pręgowany, prążkowany'): Karszunas 1625 K; Karszunowna 1830 Srj.

KRAWEL, KRAWIEL (wsp. łot. n. Kravelis): Krawiel 1662, 1669 Ad G; Krawielis 1780 Int J; Krawielewicz 1627 K; Sophia Krawielucia 1656 Ad G; Krawielowa 1660, 1668 Ad G; Elisabethae Krawielicia 1685-1731 Dgl KR; Elisabetha Krawieliczowna 1729-1771 Ut KR.

KRYSZAJTYS (może związek z lit. n. o. Kriščaitis lub Krišas, Zinkevičius, 2008, s. 411, 285): Krysaytis 1677 Šiluva; Krifas 1757-1767 Rag; Krisz 1665 K.

KULWEIT (wsp. lit. n. Kulvaitis, Kulveitis < Kùlvis?): Kutwaicia 1648 Lnk1 J; Caterina Kulwaÿczia 1721 Lnk1 J; Kułwaytis 1757, 1760 Tauczuny, Kdn KR; Kulwaytis, Anna Kułwayczia 1763 Tauczuny, Kdn KR; pracowitey Katarzyny z Kulwayciow 1829 Kdn M.

LAMUT (wsp. lit. im. Lamutis): Łamuytis 1677 Šiauliai [Szawle].

LANKAJTES (wsp. lit. n. Lankaitis < Lánkas): Lankaytis II p. XVI w., aps. Rt.

LEJSZA (lit. leišà, leĩšis 'powolny, ciężki, ślamazarny człowiek; (pej.) Litwin; mieszkaniec Auksztoty'): Leysiewicz, Leyszowna 1668 Krž KR; Leyszowa 1685-1731 Dgl KR; Leysa 1691-1781 Vdn J; Magdal. Leyfze 1729-1771 Ut KR; Leifz 1797 Pnd.

ŁOKUĆ (lit. lokútis 'niedźwiedziątko'): Локутович 1537 vls. Шов’довское; Łokuytis 1648, 1685, Lokuytis 1688 Grz J; Lakutis 1735 Skd; Łokuciewfki 1739-1759 Krns J; Łokuciewska, Łokuciewfka 1740-1759 Krns KR.

ŁOWKIS (lit. n. Laũkis (of. Lawkis), Laukỹs < lit. laũkis ‘łysy; goły; (zwierzę) z białą plamką na czole'): Eowkis 1698 Lauksodis, 1689 Ad G, 1765 St. Sitańskie w. Puczakany aps. Ukm, 1780, 1782 Int J, 1795 dw. Ad w. Bagdžiūnai, 1802, 1827 Ad M; Cristina Łowkisowa 1829 Ad M; Catharina Eowkisowna 1827 Ad M; Ловкисъ 1882 Ракшской в.

MAJNO, MAJNA (prus. n. o. Maine (?), Mainote (Lewy, 1904, s. 52) i dawna n. m. Stubice-Mayno; por. też Ivoška, 2018, s. 94): Maynis 1664 Ad G; Maẏnas 1678 dw. Ps, w. Rogowce; Maynas 1751, 1759, 1771 vls. Ps., w. Ragaudžiai.

MAKSZYS (lit. makšỹs 'człowiek wyrządzający drugim szkody, szkodnik'): Makszys 1760-1790 Link KR; Maxis 1708-1740 Link KR; Maxis, Maxijz 1729-1771 Ut KR; Makszewski 1626 K.

MARGATIS (lit. Márgaitis, Margáitis < Márgis < lit. márgis, mar̃gis 'coś kolorowego, wielobarwnego'): Margacze 1757-1767 Rag.

MEJŁUK, MIEJŁUK (<*Meiliukas < lit. meilius 'fajtłapa, ciapa' i sufiks deminutywny -ukas): Meylukaytis, Margaritha Meylukowa 1678-1691 Krns KR.

MEŁGAŁW (wsp. łot. n. Melgalvis < łot. melns 'czarny', galva 'głowa'): z Grigiem Melgalwiem 1597 vls. Tendžiogala, w. Daužnagiai. 
MIEGAS (< miẽgas 'sen', miegóti 'spać' lub miẽgas 'sąsiek, zasiek, wydzielone miejsce w stodole do przechowywania zboża'?): Mieygias 1652-1672 V KR; Miegis 1677 Vilkija.

MIEGUĆ (<*Miegutis? Por. lit. miegutis < miẽgas 'sen'): Mieguć 1803, 1804, 1807, 1808, 1810, 1823, 1829 Ad M; Miegućiowna 1805 Ad M; Mieguciowa 1807, 1810, 1815, 1817, 1820, 1823 Ad M; Miegućiowa 1807 Ad M; Mieguc 1689, 1692, 1694 Ad G; 1751 Ad, w. Gruodžiai; 1815 , 1825 Ad M; Miegucz 1689 Ad G; Miegudz 1739 vls. Ad, w. Gruodžiai; Luciae Miegutowny 1764-1786 Užp KR; Miegutis 1764-1786 Užp KR, 1685-1731 Dgl KR; Miegutowicz 1685$1731 \mathrm{Dgl} \mathrm{KR}$.

MIKOŁUĆ (<*Mikaluitis?): Joannes Mikałuytis 1602 Jon; Mikołuytis 1617 Jon, 1643 Grz J; Mikoluytis 1681 Grz J, 1756 Jon.

MIKUŁANIEC (<*Mikulanis?): Mikulanis 1671, 1672 par. Pun; 1830 Srj; 1678-1693 Užp KR; 1729-1776 Ut J; Martha Mikułaniowa 1685-1731 Dgl KR; Mikulan 1624 dw. Aknystos, w. Bernatkavičiai; 1666 Ad G.

MIŁEJSZO (wsp. lit. n. Mileiša, Mileišis i n. m. Mileišiškès — ob. dzielnica Wilna): Miteyfza, Mileyszowa 1708-1740 Link KR; Mileyszysz [!], Miłeyszowna, Miłeyfzowna, Mileyszowna 1760-1790 Link KR; Miłeýsis 1694 Kn sen., w. Jachimiškès; Stanisław Mileyszys 1705 dw. Graužai, w. Grawzyki; Милейшовичъ 1528 Vdk; Милейшайтисъ 1528 Rs; Miłeysziunas Vb J $1678-1680$.

MIŁONAJĆ (wsp. lit. n. Milanaitis): Milianaytis 1666 par. Pun; Millionis 1656 Krž KR; Miłonis $1678-1680 \mathrm{Vb} \mathrm{J}$.

MINAUT (prus. n. o. Minaute, Mynawthe, Mynawte, Mynaute, Mynauthe, Mynnaudt, Minawte, Menawthe, Menaute, Trautmann, 1974, s. 60): Минайтис 1537 vls. Dirvènai; Minaytis Krns KR 1678-1691; Минавтаитис 1592 vls. Vdk.

MINKSZTYN (lit. minkštas 'miękki'): Thomæ Minxtinalis 1652-1672 Vdn KR; Anna Minksztynowa 1729-1771 Ut KR; Vincentus Minksztas 1818 Švnč M.

MISIUKAJTIS (wsp. lit. n. Misiukaitis): Hedwige Misiukaycia 1660 Paparčiai KR; Zofia Mifukayciowna 1703 Noč KR.

MISIULANIEC (<*Misiulionis?): Jan Misiulanis 1673 par. Ukm, w. Gumbele; Casimiro Misiulaniec $1691-1781 \mathrm{Vdn} \mathrm{J}$.

MUSIULANIEC (<*Musiulionis?): Barbara Musiulaniowna 1824 Šr, Kiaukliai M; Musiul 16781693 Užp KR; Musiulis 1764-1786 Užp KR.

NARWAT ( $<$ Narvaitis < lit. n. Narvỹs? Ta ostatnia forma jest notowana w LPŽ): Casper Narwaytis 1617 Jon KR; Jan Norwaytis 1694 vls. Krt, w. Baltmiškiai.

OSZKIEWICZ (<*Oškevičius < *Ožkevičius < lit. ožkà 'koza'?): Casimiri et Annæ Oszkiewicz $1729-1771$ Ut KR.

OSZKAŁO, OŻKAŁO (lit. (gw.?) ožkela < ožkelè, ožkà 'kózka, koza'): Oszkeła, Oszkela 1654 Ps; Oszkielis 1678-1693 Užp KR, 1691 Skaruliai; Anna Oszkielicia 1687-1719 Vb J.

PANELAS (lit. ponẽlis 'panicz; słaby, mały pan', panẽle 'panienka; śnieżyczka przebiśnieg, łac. Galanthus nivalis; przywrotnik pospolity, łac. Alchemilla vulgaris; ostróżka, łac. Delphinium'): Ponelacze 1769-1822, 1769-1864 Rag; Ponelatis 1769-1822 Rag; Poneleit, Ponelyte 17691864 Rag.

PAPUCIS, PAPUCZYS (d. lit. ap. paputis 'nadęty'): Tomulis i Bartlomiey Paputelis 1673 par. Ukm, w. Heynary; Thomas Paputys 1761 de Jawneykie [Jauneikai], Jon J.

PIEKUTIEN, PEKUTIEN, PEKUTIEŃ (< Piekutiene < Piekutis?): Mathai Pekuitis 1600 Jon; Piekus 1755 r. Krtn, w. Nausėdai, w. Užpelkiai, sen. Inpiltis [Impiltis]; Pekute 1769-1822 Rag.

PIERSZTEL, PERSZTEL (lit. pirštẽlis 'mały palec'): Elizabeth Pierstelowa 1659 Ad G; Helena Pierstelowa 1660 Ad G.

PIWISZKIS (zniekształcone n. Pieviškis? < *pieviškis 'mieszkaniec łąki' < lit. pìeva 'łąka', analogicznie do ap. typu kalniškis 'mieszkaniec gór' < kalnai 'góry'): Bartłomiey Piwifzkis 1827 par. Zr, w. Kukle [jedyne poświadczenie bez „e"]; Elibieta [!] Piewiszkiowa, Dominik Piewiszkis 1835 par. Zr, w. Azoreyscie. 
PLIKUS (lit. plikas ‘łysy, goły’, plikis ‘człowiek łysy; człowiek nagi; biedak, nędzarz’): Julko Plikus $1561 \mathrm{~K}$.

PREDYKAJT (*Pridikaitis < lit. im. Prydikis $<$ niem. im. Friedrich? Por. też łot. n. Priede $<$ łot. priede 'sosna, świerk' itp.): Pridzikate, Pridzik 1769-1822 Rag.

PRESKI (lit. prèskas 'przaśny, bez zakwasu, niekwaśny; niesłony, o delikatnym smaku'; por. lit. n. Prèskiẽnis): Anaftazia Preskaýcia 1675 Lnkl J; Mariana Prefkiowa 1691-1719 Krns KR; Preskinis 1663 Lnkl J.

PULAKIS (lit. púlakis 'człowiek o chorych oczach; śpioch'): Antoni Pułakis 1765 vls. Pienionys, m. [!] Andraniszki; Pułak 1693 par. V, dw. Dubovsčizna, w. Minikanie; Maryanna Pułakowna 1702 Noč KR; Pułak 1798 Šd graf., w. Velžiai; Pułakowski 1816 Sd.

RADYKO (lit. n. Radikas (pot. też Radýka), Radỹkas, Radikis, Radỹkis, Rodikis < Radỹs, Rãdis, etymologia niepewna - por. też Radyk 1811, Paštuva/Kvesai w rej. kowieńskim (Maciejauskienė, 1993, s. 104): Radyka 1662, 1824 K; Radykowna 1741 Žeimiai Jon; Magdalena Radykowa „z Koniuch” 1763-1791 M, 1783 K; Радыко 1882 Красносельская в.

RAPOTA, RAPOTI, RAPACKI ((n. m. Rapaty) < prus. n. o. Rapote, Rapotho, Rappoth, Trautmann, 1974, s. 82, Bijak, 2001, s. 171, por. też prus. rapa 'anioł' (EV) oraz prus. n. o. Rapotin 1352 (Ivoška, 2018, s. 99)): Rapacka 1662, 1666, 1668 Paparčiai KR; Rapaytis 1663, 1665 Krž KR; 1647 vls. Vilkija, dw. Varputininkų [dop.], w. Grymaycie; Rapacki 1667 Krž KR; Panauкiŭ 1882 Олотская в.

RASZAT (<*Rašaitis, etymologia niepewna): Pamaŭmuc 1537 vls. Gandinga; Raszaytis 1611 Rt. RAUBUĆ, ROWBUĆ (wsp. lit. n. Raubutas, Raubutis): Raubuytis 1660, 1681 Grz J.

RIEKEIT (riekas, griekas 'grzech', więc riekaitis 'grzesznik'? Por. też rẽkas = rèksnys 'krzykacz'; rẽkas 'krzyk, wrzask'): Cristinam Rekaicia 1653 Lnk1 J.

RODAJTYS (wsp. lit. n. Rodaitis): Грыгорей (Григорей) Радайтисъ, Грегоры Родайтисъ 1528 Krž; Войтко Родайтисъ 1528 vls. Užventis; Павел Родайтис 1537 в. Шов'довское; Rodaitys 1662 vls. Krk, w. Pokorkle; Anna Radayte 1670 Krž; Radaytis 1695 Paj, dw. Švėkšna, woyt. Mikuziewe [Mikužiai]; Rodaytis 1698 Lauksodis; Zophia Rodaycia 1702 Dt KR.

RUSKUL (wsp. lit. n. Ruskulis, łot. n. Ruskulis, Ruskuls, Ruskuls): Ruskul 1810, 1812 Imbr KR.

SARGALIS, SARGIALIS, SERGIALIS, SIERGIALIS, SIERGIEL (lit. sargãlis, sargãlius, sergalis, sirgãlius 'człowiek chorowity'): Helena Sargaylowa, Magdale Sergaylowa 1729-1771 Ut KR; Anna Sargiejłowna 1729-1776 Ut J; Саргелевичь 1802 Šiauliai.

SAUGUT, SAŁGUT, SOŁGUT, SUŁGUT, SUŁGUTT (prus. n. o. Sawgut(t)e, Sawgotthe, Sowgutte, Saugutte, Trautmann, 1974, s. 90): Joannes Sauguytis 1677 Grz J; Joannes Saugwitis 1670 Grz J.

SAWUĆ (*Savutis, zapewne od Sãvas < brus. i ros. im. Савва, Сава): Woyciulis Sawucianis 1673 par. Ukm, w. Sawucie [!].

SEREWIS (< Sereivis? Etymologia niejasna): Serewiczowna 1660 Paparčiai KR.

SILKE (lit. silkìis 'śledź', silike ‘śledź, łac. Clupea; chudy człowiek'): Martini Silke/Silkiewicz 1663, Martini Silkiałe 1667, Martini Silkie 1669 Paparčiai KR; Silkutaytis 1642 Rs, w. Meldikviršiai; Catharinae Silkicia 1644 Švnč G, Matheus Silkinenas 1643 Švnč G, Jeduige Sylkucia 1643 Švnč G; Heduigem Silkinaycia 1690 Lnk1 J; Magdalena de domo Silkiewiczowna 1729-1771 Ut KR; Mathias Sylkiewicz, Jacobus Silkiewicz 1729-1776 Ut J.

SKORULSKI ( $<$ Skorule, lit. Skaruliai, dawna wieś i posiadłość rodu Skorulskich, ob. dzielnica miasta Jonava k. Kowna < lit. skarà 'duża, zwykle wełniana chusta na plecy, głowę; ścierka, szmata, łachman, gałgan; marna, znoszona, pozdzierana odzież', skãris 'coś znoszonego, zniszczonego, obszarpanego, oberwanego', skárti '(o odzieży) strzępić się, pruć się'): Skorulski 1600 par. Upyte i in.; 1625 K; 1720 Švenčionys; Skorulska 1668, 1679, 1682 Paparčiai KR; 1783 Medeksze; Skorulfki 1669, 1679, 1680, 1681 Paparčiai KR; 1816 Sd; Скорульская 1882 Субогская в.; Скорульский 1882 Курклевская в.; Скорулевич 1542 dw. Кгекгужин.

SKORWID (lit. n. Skorvydas): Nikodema Skorwida (kunig.) [księdza] 1829 Mrc KR.

SOWUL (lit. n. Savùlis < Sãvas < brus. i ros. im. Савва, Сава, lub od im. Savẽlijus): Georgium Sowulinos 1679 Lnkl J; Euam Sawulowa 1689 Lnkl J. 
STANKUĆ $(<$ Stankutis < Stankus < pol. im. Stanisław lub jego odpowiedniki w innych językach słowiańskich): Мартис Станкгутис 1592 vls. Vdk, w. Поонтые.

STRASDUN (wsp. lit. n. Strazdūnas, Strãzdas < lit. strãzdas 'drozd'): Strazduanis 1621-1646 Vb J.

SUDAJTIS (lit. n. o. *Sudas, Sudeĩkas, Sudeĩkis i prus. n. o. Sude, Sudeke, Sudenne, Trautmann, 1974, s. 100, Ivoška, 2018, s. 60): Судаŭmuс 1537 vls. Tverai; Sudaỳtis 1694 vls. Krt, w. Būdviečiai; 1659 Pun.

SUREL (może od skróconej lit. n. o. złoż. na Sur-; por. też lit. sūrelis < sūris 'ser' i sufiks deminutywny -elis): Surelis 1598 par. Ukm, mst. Panemunis; 1685-1731 Dgl KR.

SWIRKAITIS (lit. n. o. Svirka, zapewne poch. słow., i wsp. lit. n. Svirkas): Januka Swirkoycia [dop.] 1651 woj. wileńskie (WKL), w. Drevininkai.

SZALUNAS (wsp. lit. n. Šaliūnas): Szalunas 1830 Srj [kilka poświadczeń]; Rozalia Szalunowa $1830 \mathrm{Srj}$.

SZAMEITAT (< lit. n. Žemaitáitis): Szamacze, Szamaitacze, Szamaitatis, Szamat 1757-1767 Rag; Szamatis 1757-1767, 1769-1822 Rag; S3amate 1769-1822 Rag.

SZAWDYLAS (lit. šiaudẽlis 'łodyżka lnu; słomka, rurka w kształcie źdźbła słomy; wypiek w kształcie słomki', šiaudẽlè 'dudek, łac. Upupa epops'): Szaudalis 1663, 1662-1689 K; Edwiga Szawdełowa 1695 Ad G.

SZCZESIUL (etymologia niejasna, może związek z lit. n. Česiùlis): [?] Bafili Sczezul 1693 Ad G.

SZEJBUT (wsp. lit. n. Šeibutas): Szeybut 1641 Švnč par. G; 1798 vls. Mažeikiai, w. Poškènų [dop.]; 1798 Šd graf., Pavartyčių k.; Szeybutas 1701 Lauksodis; Anastasiæ Szeybutowna 1764-1786 Užp KR.

SZERSZNOWICZ (*Šeršnavičius < lit. n. Šeršnys < lit. šeršnỹs 'osa'): Szerszniewicz 1792 Alexoto (1791-1801/1827 K M) [Aleksota to ob. dzielnica Kowna].

SZTURGULEWSKI ( $<$ *Sturgulis? — etymologia niejasna, por. też lit. šturgelis, w regiolekcie z okolic Szyłokarczmy 'przedmiot do straszenia ryb (by je zapędzić do sieci)'. Wymienność Szti St- potwierdza choćby fakt, że w księdze J par. Lnkl (r. Vlkv) występuje zarówno n. Sturaitis (1651, 1657) i Sturaycia 1679, jak i Szturaitis 1665, Szturaytis 1689 [2 razy], 1691): Tomasza Sturgulewskiego kunigas ['ksiądz'] 1776 Krns.

SZUKIANIEC (może derywowane sufiksem deminutywnym od lit. n. Šukéna $<$ Šukỹs): Szukianiec 1708-1740 Link KR, 1806 Švnč M; Szukian 1801 Švnč M; fzukayła de Szukiany 1678-1680 Vb J.

SZWIRAKIS (< lit. žverrãkis 'człowiek o oczach jak u zwierzęcia'): brak poświadczeń tej postaci, ale oboczność $s z(\breve{S}) / \dot{z}(\check{z})$ uprawdopodabniają następujące poświadczenia: Szwinakis 1692, 1694 Skaruliai / Zwinakis $1795 \mathrm{Klm}$ dw. [3 różne osoby]; Zwinakis 1747, 1751 w. Paverpenis [2 różne osoby], 1751 w. Paverpenis [2 różne osoby]; Szwirblowna 1760-1790 Link KR [por. lit. n. Žvirblỹs]; fzwerelis 1691-1781 Vdn J [por. lit. n. Žverrelis]; Szwerys 1779-1781 sen. Palanga, w. Łozdyniki [por. lit. n. Žverì̀s].

TANANIS (<Tananas, of. też Tanano, pochodzenie słowiańskie lub od lit. imienia Tãnas < Antãnas 'Antoni'; możliwy też związek ze skróconymi lit. n. o. na Tan-, Zinkevičius, 2010, s. 30): Tananis 1609 par. Ukm, dw. Panemunis, w. Cywancy; Tananiewicz 1830 Srj.

TOMSZYS (d. lit. n. Tamšys, Tomšis, zapewne od lit. imienia Tòmas 'Tomasz'): Tomfzene, Tomfzin 1757-1767 Rag; Tomfziunas Vb J.

TREKIEL (*Trekelis, może od Trakẽlis < Trãkas < trãkas 'leśna polana, przecinka', (gw.) trãkas 'łysy; oszalały', trakùs '(o wietrze) porywisty, (o koniu) porywczy, gwałtowny, narowisty', tràkti 'szaleć, dokazywać, wariować'): Martinus Trekelis 1657 Ad G [jedyne poświadczenie].

TRIBILO (< lit. tribilà 'papla, pleciuga, pleciuch'): Annam Matthæ Tribilas filia, 1621-1646 Vb J; Mathia Trybelis 1759-1787 Krns KR.

UNDRUL (wsp. łot. n. Undrulis, por. też lit. Undráitis < Andráitis, Uñdrius < Añdrius 'Andrzej'): Vndrutenas 1685-1731 Dgl KR; Catharina Undrulowa 1691-1719 Krns KR; Undrulanis 1764-1786 Užp KR.

UNDRUNAS (wsp. lit. n. Undrūnas < Andriūnas < lit. im. Añdrius 'Andrzej'): Undrunas 1649 Švnč G; Undrunas 1691-1719, 1719-1740, 1740-1759, 1759-1787 Krns KR, oraz spis mieszkańców 
1846 [b. liczne poświadczenia]; Undriunas 1691-1719, 1719-1740 Krns KR; Undruniowa 1691-1719, 1719-1740, 1740-1759 Krns KR; Undrunowa 1719-1740, 1740-1759, 1759-1787 Krns KR; Undrunowna 1719-1740, 1740-1759 Krns KR; Undrunoycza 1759-1787 Krns KR; Undruniowna 1808-1820 Vad KR.

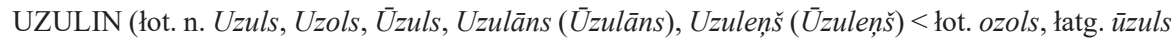
'dąb'): Basilius Vzulis 1685-1731 Dgl KR.

WALIO (etymologia niejasna, por. lit. Valis, Valỹs < Vãlentas, Valeñtas 'Walenty'): Walis [wiele poświadczeń, najstarsze 1606 K]; Valis 1633 Lnkl J; Elisabeth Walia 1678 Paparčiai KR; Walys Uciana J 1729-1776; Catarina de Domo Waliowna 1760-1790 Link KR.

WASKIAN (lit. Vasas < Vosỹlius, ros. Василий, brus. Baсиліü): Vaskian 1670 Ad G, Waskan 1668 Ad G; Waskienas, Woskienas 1697 Ad G; Elisabetha Wofkienia 1697-1719 Vb J.

WEITUSCHAT (lit. n. Vaitušaitis < lit. vaitas 'wójt'): Georgius Waitufaitis 1668 Lnk1 J.

WERELIS (etymologia niejasna): Chriftophorus Werelis 1679-1693 Krns J.

WERKUN (*Verkunas, *Verkūnas, por. lit. ap. virkũnas, verkuõnis, virkuõnis, płaczek, płaksa, beksa' < ver̂kti 'płakać'): Sczesny Werkunas 1627 K; Samuel Werekunas 1694 par. Dt J.

WEZALIS, WEZEL (lit. ap. vèzas, vezzdas 'kij, laska' i sufiks deminutywny -elis, lub Vėžẽlis $<$ Véžỹs $<$ lit. ap. vėžỹs 'rak'; jak się wydaje, $z$ oraz ź są w poświadczeniach używane wymiennie): Wezelis 1604 mst. Kdn; Marcin y Paweł Wezelowie 1624 dw. Aknystos [k. Dobejek], w. Bernatkavičiai; Wezeła [dop.] 1625 K; Agnes Wezelowa de Wezele [dopisek na karcie: Vežẽliai (w.)], Vdn KR 1652-1672; Wezel 1655, Wezel, Wezelowa 1669 Ad G; Wezelis 1663 Švėkšna, 1607, 1610 K, 1659 Krž KR, 1609 par. Ukm dw. Panemunis, 1632 vls. Telšiai, dw. Gawrelių [dop., niejasna forma mianownika]; Heduigis Weźelowa 1665, Weźelis 1661, 1666 Krž KR; Wezelis (de Wezele) 1678-1693 Užp KR, 1652-1672 Vdn KR; Wezelowa (de Wezele) 1678-1693 Užp KR; Alberti Weźalis, Alberti Weźelis, Albertus Wezelis 1685-1731 Dgl KR.

WIDEN (lit. im. Vydẽnis i prus. n. o. Wydenne, Kuzavinis i Savukynas, 2009, s. 326, Trautmann, 1974, s. 117): Catharina Widenicia 1652-1672 Vdn KR; Widzanski 1664 par. Punia; Widzienas 1689 Ad G; Chrystyna Widzianicia 1708-1740 Link KR; Widzienicia, Andreæ et Cristinæ Widzianow, Anna Widzianowa 1729-1771 Ut KR.

WIDRUK ( $<*$ Vidrukas, por. lit. n. Vidrà < lit. vidrùs 'gwałtowny, porywczy, raptowny, nagły; silny', výdra, vidrà 'wichura, burza'): Casimiri Wydruk, Marjannæ Wydrukowa 1740-1760 Link KR; Eduiga Widrucia 1694 Ad G.

WIEKSZA (może związek z lit. véikus 'szybki', viêkas, viekas 'moc, siła', por. wsp. łot. n. Vekšs): Martino Wekszała 1665 Lnk1 J; Casimirus Weks[s]ie 1697-1719 Vb J; [?] Ludovici Wiekfzl 1660 Paparčiai KR.

WIĘCKIEL $(<*$ Venckelis < Veñckus < Veñcius, zapewne pochodzenie słowiańskie z lit. sufiksem): Jacobi Węckielis 1691-1719 Krns KR; Catharina Więckielunowa 1704 Noč KR.

WILMONT (lit. im. złoż. Vilmantas): Wilmont 1697, 1701 Noč KR; Stanislaus Wilmąt 1705 Noč KR; Elena Wilmontowna 1699 Noč KR; Eufrazina Wilmontowna 1700, Maryna Wilmątowna 1704, Eufrofina Wilmątowna 1706 Noč KR.

WILNAT (<*Vilnaitis < Vil̃nius? Por. lit. vilna 'wełna'): Orsula Wilnaÿcia 1620 Lnkl J; Caterina Witnaicia 1630 Lnk1 J; z markiem wilnaiciem, Marek wilnaitys 1637 vls. Gardai, w. Borÿnianÿ.

WIRBUŁ (wsp. łot. n. Virbulis): Mathiam Wirbulis 1659 Lnkl J; Marta Wirbulowna de [?]ongo, 1719-1740 Krns J.

WOITUN (wsp. lit. n. Voitunas, Vaitūnas, Vaitunas): Waytunas, Bogumila Waytuniowa, Ludowica Waytuniowa 1810 Imbr KR; Gidruta [!] Waytunowa 1678-1693 Užp KR; Evæ de Domo Waytuniowna 1807 Imbr KR.

WOJCIANIS (wsp. lit. n. Vaičionis): Jacobus Woycianis, Bartholomæi Woycianis 1652-1672 Vdn KR; Jana Woyciania [dop.] 1665, 1685 K; Waycienas 1685-1731 Dgl KR, 1759-1787 Krns KR.

WOJTKIEŁO (wsp. lit. n. Vaitkelis): Jakubellis Woitkieliozięczifz [sic!] 1562-1564 K, Jakuba Woitkieliozęthifz [!] 1566 K (< lit. ap. žéntas 'zięć', por. Ragauskaite, 2018, s. 62-66); Pauluka 
Woyttkiela 1660 V; Woiciech woitkielis 1637 vls. Gardai, w. Kubakie; Stanisław Woitkiełaitÿs

1662 vls. Gardai, w. Degucie; Barbara Woytkielowa 1685-1731 Dgl KR; Woytkielewicz 1830 Srj. WOJTOKAS (zapewne od Vaĩtkus, Vaitiẽkus, Vaitiẽkas, Vaitiekà < pol. imię Wojciech); Dorotea Waytokaycia 1727 Dt KR; Christyna Waytakowa 1729-1771 Ut KR.

WYSKIEL (wsp. lit. n. Viskelis i prus. n. o. Wyske, Trautmann, 1974, s. 119): Wiskialis, Wiskielis 1729-1771 Ut KR; Anna de domo Wiskieliczie 1729-1771 Ut KR.

ŻARNIEWICZ (lit. ap. žarnà 'jelito'): Christophorus Zarniew/ki 1719-1740 Krns KR; Jan Żarniewicz 1765 St. Pupańskie, w. Pupany, aps. Ukm.

ŻELWETRO (wsp. lit. i łot. n. Želvetro): Zelwetryn 1809 Int J.

ŻYNDA, ŻENDA (lit. n. Žìnda, Žiñdis < lit. žindyti ${ }^{\text {' }}$ o kobiecie) karmić piersią; (o samicy zwierzęcia) karmić młode' oraz lit. ap. žindà 'dawny rodzaj uspokajającego smoczka dla niemowlęcia (zwykle kawałek posłodzonego chleba owinięty w szmatkę); odłamki, okruchy powstające przy krojeniu tępym ostrzem': Zynda 1697, 1699, Maryanna Zyndowa 1699, Elizabeth Zyndaycia 1700 Noč KR.

ŻYWANOWSKI (prus. n. o. Zivan, Dziwan, Trautmann, 1974, s. 25): Joannem Ziwonaÿtis 1620 Vlkv r., Lnkl J.

Wyekscerpowane antroponimy, będące spolonizowanymi formami litewskich nazw osobowych, egzemplifikują zarazem opisane w literaturze przedmiotu (Maciejauskienè, 1991, s. 169-214; Zinkevičius, 2010; Zinkevičius, 2011) mechanizmy polonizacji fonetycznej i morfologicznej, a w odniesieniu do współczesnej grafii języka litewskiego (w czasach, z których pochodzą poświadczenia, jeszcze nieustabilizowanej) — także graficznej. Nazwiska wykazują wysoką wariantywność graficzną (Wilmont/Wilmąt, Bomblis/Bąblis, Jakubełaytys/ Jakubelaytis). Oprócz naturalnego, szczególnie przed XVIII w., nieustabilizowania formy nazwiska (i samego języka) powodem jest i fonetyka, na przykład typowa dla mechanizmów polonizacyjnych zmiana $o>a$ : Woycianis $>$ Waycienas, Boraitys (> Baraytis) > Barat (jak wskazuje Maciejauskienè, 1991, s. 172, zmiana ta następuje raczej w temacie niż w końcówce, co i w omawianym tu materiale znajduje potwierdzenie). Odwrotna zmiana $a>o$ jest z kolei częsta w końcówce: Dowgała $>$ Dowgajło, Radyka $>$ Radyko. Innymi typowymi zjawiskami fonetycznymi wymienionymi przez V. Maciejauskienè (1991, s. 172), a znajdującymi odzwierciedlenie w badanym materiale, są monoftongizacja dyftongu uo $>$ o (Juoda $>$ Jodda), a także zmiana au > aw, ow (Szaudalis > Szawdylas, Laukis > Łowkis), ai > oi (Jakubełaytys > Jakubiatojć). Jak ponadto wskazuje A. Ragauskaitè (2018, s. 57), odbiciem polonizacji (slawizacji) jest też zapis ie zamiast $e$, w omawianym materiale egzemplifikowany np. przez Kierkla $<$ kerklỹs, Czekień $<$ Čekenis, oraz $\check{z}>z$ (por. Wezalis, Wezel).

Najistotniejszą zmianą morfologiczną jest odrzucenie litewskiej końcówki fleksyjnej męskiej: Kulvaitis > Kulweit, Vydenis > Widen, Aufztolis > Ausztol, zdarza się także zastąpienie jej sufiksem polskim: Czyżelis $>$ Czyżelski, przy czym szczególnie typowe są w tego typu substytucjach słowiańskie sufiksy patronimiczne -ewicz, -owicz w miejsce litewskich sufiksów patronimicznych -aitis, 
-ènas, -onis, -ūnas (por. Ragauskaitè, 2018, s. 58, 59): Battukiewicz, Dyrsowicz, Miegutowicz, Tananiewicz, Żarniewicz. W nazwach osobowych kobiet częste są polskie sufiksy -owa: Baltuciowa, Czepalenowa, Dayniowa, Gieżyniowa oraz -owna: Bargiulowna, Łowkisowna, Waytuniowna, rzadziej litewskie: Bałtunienia, Krawielicia, Tomfzene, Wofkienia.

Istotna część wyekscerpowanych ze współczesnego antroponomastykonu polskiego nazwisk podejrzewanych o pochodzenie bałtyckie nie znalazła poświadczeń w kartotece. Są wśród nich nazwiska o możliwej genezie pruskiej (ew. jaćwieskiej), jak np. Alnis, Antyk, Bajno, Kojtek, Miszto czy Wutrych/Wotrych ${ }^{7}$. Brak ich poświadczeń niekoniecznie musi tę genezę całkowicie wykluczać, gdyż na obszarach, z których pochodziły źródła wykorzystane przez twórców kartoteki, antroponimy pruskie mogły występować w stopniu nieznacznym, zaś te obecne we współczesnym onomastykonie polskim mogły doń dotrzeć bezpośrednio z Prus Wschodnich, należących przed 1945 r. do Niemiec (z wyjątkiem przyłączonego do Litwy w 1923 r. Kraju Kłajpedy). Dotyczy to w szczególności nazwisk o charakterystycznych morfologicznych cechach wskazujących na pochodzenie z Litwy Małej (tzw. Pruskiej), jak Adumejt, Berenat, Birenat, Wannuschkat, Weiduszat. W bardzo ograniczonym zakresie występują też w kartotece nazwiska o możliwej (jak Dadulewicz, może od Daduḷs — gw. forma łot. im. Tadeušs) bądź niewątpliwej (Lielbriedis) genezie łotewskiej.

Nie odnaleziono także poświadczeń niektórych nazwisk polskich o możliwej motywacji apelatywami litewskimi, jak np. Audul (por. lit. ap. audùlis 'tkacz'), Bejżemski (bežẽmis, bežẽmininkas 'bez ziemi, bezrolny'), Begedza, Begiedza, Bugieda (begèda 'bezwstyd; osoba bezwstydna'; begédis, bẽgédis 'bezwstydnik, świntuch') ${ }^{8}$, Bendryn (bendrinis 'pospolity, wspólny, ogólny'), Biżuta (bižè 'wesz') ${ }^{9}$, Bryzgalski (brìgalas, brìzgas, brỹzgas 'gałganek, szmatka, skrawek materiału'), Burbutowski (burbùtis 'rodzaj chrząszcza'), Burel (burêlis 'baranek, jagnię' lub būrẽlis 'kółko, gromadka'), Czupiel (čiùpelis, čiùpèlis, čiúpélis, čiùpele 'maruda, guzdrała, osoba powolna, zwlekająca z działaniem'), Kowejsza, Kawejsza, Kowiejsza (kaváiša 'noga') i in. Generalnie nie udało się również znaleźć poświadczeń nazwisk odmiejscowych, derywowanych sufiksem -ski od spolszczonych toponimów litewskich, jak np. Antokolski, Batygolski, Rosieński czy Urdomiński.

\footnotetext{
${ }^{7} \mathrm{Na}$ temat oboczności $u$ oraz $o$ w zapisach pruskich nazw własnych w dokumentach zakonu krzyżackiego, por. Ivoška, 2015, s. 46, przypis 12.

${ }^{8}$ Por. też imię bohatera Begiedis 'bezwstydny' (Dowojna Sylwestrowicz, 1894, s. 390-394).

${ }^{9}$ Może spolszczona litewska forma żeńska nazwiska: Bižiūtè $<$ Bižys.
} 


\section{ROZWIĄZANIE SKRÓTÓW NAZW MIEJSCOWOŚCI ORAZ WSI I/LUB PARAFII}

Ad - Adutiškis (Hoduciszki)

$\mathrm{Al}$ - Alytus (Olita)

Als - Alsèdžiai (Olsiady)

Dgl — Daugailiai (Daugiele)

Dt - Dotnuva (Datnów)

Grz — Gruzdžiai (Gruździe)

Imbr — Imbradas (Imbrody)

Int — Inturkè (Inturki)

Jon - Joniškis (Janiszki)

$\mathrm{K}$ - Kaunas (Kowno)

Kdn - Kėdainiai (Kiejdany)

$\mathrm{K} 1$ - Kuliai (Kule)

Krk - Krakès (Kroki)

Krns - Kriaunos

Krsn - Krosna (Krasna)

Krt - Kartena (Korciany)

Krtn — Kretinga (Kretynga)

Krž — Kražiai (Kroże)

Link — Linkmenys (Łyngmiany)

Lnkl — Lankeliškiai (Łankieliszki, rejon wyłkowyski), w. i par.

Mrc - Marcinkonys (Marcinkańce)

Ms - Mosèdis (Masiady)

Noč — Nočia (Nacza, brus. Нача)

Paj — Pajūris (Pojurze)

Ps - Pasvalys (Poswol)

Pun - Punia (Punia)

Rag - Ragainè (Ragneta)

Rt - Rietavas (Retów/Retowo)

Rk - Rokiškis (Rokiszki)

Rs - Raseiniai (Rosienie)

Sd - Sedos (Siady)

Skd - Skuodas (Szkudy)

Srj - Seirijai (Sereje)

$\breve{S} d$ - Šeduva (Szadów)

Šln — Šiaulènai (Szawlany)

Švnč — Švenčionys (Święciany)

$\breve{S r}$ - Širvintos (Szyrwinty)

Taur — Tauragè (Taurogi)

Ukm — Ukmergè (Wiłkomierz)

Ut - Utena (Uciana)

Užp — Užpaliai (Użpol/Uszpole)

$\mathrm{V}$ - Vilnius (Wilno)

Vad - Vadokliai (Wodakle)

Varn - Varniai (Wornie)

$\mathrm{Vb}$ - Vabalninkas (Wobolniki)

Vdk — Viduklè (Widukle)

Vdn - Videniškiai (Widzieniszki) 
Vlk — Valkininkai (Olkieniki)

Vlkv — Vilkaviškis (Wyłkowyszki)

$\mathrm{Zr}$ - Zarasai (Jeziorosy)

\section{ROZWIĄZANIE POZOSTAŁYCH SKRÓTÓW}

aps. (lit. apskritis) — d. powiat (ujezd) w Wielkim Księstwie Litewskim

dop. — dopełniacz

dw. — dwór

$\mathrm{G}$ - księga urodzeń

$\mathrm{J}$ - księga zaślubionych

KR - księga chrztów

kr. mot. - matka chrzestna

lit. — litewski

łatg. — latgalski

łot. - łotewski

$\mathrm{M}$ - księga zgonów

mst. - miasteczko

n. - nazwisko

n. m. - nazwa miejscowa

n. o. - nazwa osobowa

par. - parafia

pol. - polski

prus. - (staro)pruski

r. - rejon

sen. (lit. seniūnija) — starostwo; gmina

vls., в. (lit. valsčius, ros. волость) — jednostka terytorialna w Wielkim Księstwie Litewskim (wołost, włość)

w. - wieś

wsp. — współczesny

złoż. — złożona

\section{LITERATURA}

Babik, Z. (2001). Najstarsza warstwa nazewnicza na ziemiach polskich (w granicach wczesnośredniowiecznej Stowiańszczyzny) [The oldest naming layer on Polish soil (within the limits of early medieval Slavdom)]. Kraków: Universitas.

Bijak, U. (2001). Nazwy miejscowe poludniowej części dawnego województwa mazowieckiego [Place names of the southern part of the former Mazovian voivodeship]. Kraków: DWN.

Cieślik ow a, A. i in. (red.). (2007-2016). Antroponimia Polski od XVI do końca XVIII wieku: wybór artykutów hasłowych oraz wykazy nazwisk wraz z chronologia i geografia [Polish anthroponymy of the 16th-18th c.: a selection of entries and surname lists, including surname chronology and geographical distribution] (T. 1-5). Kraków: Lexis, Instytut Języka Polskiego PAN.

Dacewicz, L. (2014). Historia nazwisk na kresach pótnocno-wschodnich Rzeczpospolitej (XVI$X V I I I$ w.) [History of surnames in the north-eastern part of the Polish-Lithuanian Commonwealth (16th-18th c.)]. Białystok: Wydawnictwo Uniwersytetu w Białymstoku. 
Dowojna Sylwestrowicz, M. (1894). Podania żmujdzkie [Samogitian legends] (cz. 1). Warszawa: Skład główny w księgarni M. Arcta. https://kpbc.ukw.edu.pl/dlibra/publication/36/edition/64

EV — Bezzenberger, A. i Simon, W. (1966). Das Elbinger Deutsch-preussisches Vokabular. 17 Tafeln in Lichtdruck. W: V. Mažiulis, Prūsų kalbos paminklai [Monuments of the Prussian language] (s. 59-75). Vilnius: Mintis.

Hryciuk, G. (2008). Polacy [Poles]. W: W. Sienkiewicz, G. Hryciuk (red.), Wysiedlenia, wypędzenia i ucieczki 1939-1959: Atlas ziem Polski: Polacy, Żydzi, Niemcy, Ukraińcy [Displacements, expulsions and escapes, 1939-1959. An atlas of Poland's lands. Poles — Jews — Germans Ukrainians] (s. 32-103). Warszawa: Demart.

Ivoška, D. (2015). Litauische Personennamen in den Ordensdokumenten. Acta Linguistica Lithuanica, $73,38-54$.

Ivoška, D. (2018). Baltische Eigennamen in den Dokumenten des Deutschen Ordens. Vilnius: Lietuvių kalbos institutas.

Kondratiuk, M. (red.). (1990). Bałto-słowiańskie związki językowe [Balto-Slavic language contacts]. Wrocław-Warszawa-Kraków: Zakład Narodowy im. Ossolińskich.

Kondratiuk, M. (2000). Nazwiska pochodzenia bałtyckiego w regionie białostockim [Surnames of Baltic origin in the Białystok region]. Acta Baltico-Slavica, 25, 123-150.

Kondratiuk, M. (2004). Odapelatywne nazwiska litewskiego pochodzenia w języku polskim i białoruskim [Genetically Lithuanian surnames of appellative origin in Polish and Belarusian]. W: S. Musijenko (red.), Droga ku wzajemności [A road to reciprocity] (cz. 1, s. 16-29). Grodno: GAUPP.

Kuzavinis, K. i Savukynas, B. (2009). Lietuviu vardų kilmès žodynas [Etymological dictionary of Lithuanian given names]. Vilnius: Mokslo ir enciklopedijų leidybos institutas.

Lewy, E. (1904). Die altpreussischen Personennamen. Breslau: Buchdruckerei H. Fleischmann.

LPŽ — Vanagas, A., Maciejauskienè, V. i Razmukaite, M. (1985-1989). Lietuviu pavardžiu žodynas [Dictionary of Lithuanian surnames] (T. 1-2). Vilnius: Mokslas.

Maciejauskienè, V. (1991). Lietuviu pavardžiu susidarymas XIII-XVIII a. [The formation of Lithuanian surnames, 13th-18th c.]. Vilnius: Mokslas.

Maciejauskienė, V. (1993). Lietuvių įvardijimas XIX a. pirmojoje puseje [Lithuanian personal names in the first half of the 19th c.]. Lietuviu kalbotyros klausimai, 32, 100-113.

Mikulènienè, D. (2012). Językoznawstwo lituanistyczne [Lithuanistic linguistics]. W: D. Mikulènienè, Jan Karlowicz jako animator życia naukowego i kulturalnego przełomu XIX $i$ XX w. (projekt badawczy VAT-36/2012) [Jan Karłowicz as a scholar and cultural activist at the turn of the 19th and 20th c., research project VAT-36/2012]. http://www.karlowicz.flf.vu.lt/Jezyko znawstwo-lituanistyczne-935.html

Ragauskaitè, A. (2005). XVI-XVIII a. kauniečiu asmenvardžiai [Personal names of the inhabitants of Kaunas in the 16th-18th c.]. Vilnius: Lietuvių kalbos instituto leidykla.

Ragauskaitè, A. (2018). XVII a. kẻdainiečių lietuviškos kilmės asmenvardžiai [Lithuanian personal names of the inhabitants of Keddainiai in the 17th c.]. Acta Linguistica Lithuanica, 78, 53-75.

Ragau skaitè, A. (2019). Joniškiečių vyrų asmenvardžių darybos tendencijos seniausioje Lietuvoje 1599-1621 m. Joniškio krikšto metrikų knygoje [Trends in the formation of male personal names of the inhabitants of the village of Joniškis in Lithuania's oldest baptism register (1599-1621)]. Acta Linguistica Lithuanica, 80, 177-194.

Rieger, J. (1996). Słownictwo „wileńskie” ze zbioru Leonarda Jaszczanina dziś [“Vilnius” lexis in the collection of Leonard Jaszczanin revisited]. W: J. Rieger (red.), Język polski dawnych Kresów Wschodnich [The Polish language of the former Eastern Borderlands] (T. 1, s. 79-110). Warszawa: Semper.

Rymut, K. (1999). Nazwiska Polaków: Stownik historyczno-etymologiczny [Surnames of Poles: a historical and etymological dictionary] (T. 1). Kraków: Instytut Języka Polskiego PAN. 
Sinkevičiūtè, D. (2006). Lietuviu dvikamieniu asmenvardžiu trumpiniai ir ju kilmés pavardès [Abbreviations of Lithuanian two-stem personal names and the surnames derived from them]. Vilnius: Vilniaus universiteto leidykla.

SPG - Rieger, J., Masojć, I. i Rutkowska, K. (red.). (2006). Stownictwo polszczyzny gwarowej na Litwie [Polish dialectal lexis in Lithuania]. Warszawa: DiG.

Trautmann, R. (1974). Die altpreußischen Personennamen. Göttingen: Vandenhoeck and Ruprecht. Vanagas, A. (1976). Principy i struktura slovarâ sovremennyh litovskih familij [The principles and the structure of a dictionary of contemporary Lithuanian surnames]. W: L. Kalakuckaâ (red.), Onomastika i norma [Onomastics and the norm] (s. 71-79). Moskva: Nauka.

Vanagas, A. (1994). Prof. A. Salys ir pavardžių bei vietovardžių komisija [Prof. A. Salys and the surname and placename committee]. Lietuviu kalbotyros klausimai, 34, 64-71.

Walkowiak, J. (2019). Litewskie nazwiska Polaków [Lithuanian surnames of Poles]. Poznań: Wydział Neofilologii UAM. https://repozytorium.amu.edu.pl/bitstream/10593/24507/1/ Walkowiak-2019 9788395414411.pdf

Zinkevičius, Z. (2008). Lietuvių asmenvardžiai [Lithuanian personal names]. Vilnius: Lietuvių kalbos institutas.

Zinkevičius, Z. (2010). Lietuviškas paveldas Suvalku ir Augustavo krašto Lenkijoje pavardèse [Lithuanian heritage in the surnames of the Suwałki and Augustów region in Poland]. Vilnius: Mokslo ir enciklopedijų leidybos centras.

Zinkevičius, Z. (2011). Lietuviškas (baltiškas) paveldas Balstogés vaivadijos Lenkijoje pavardèse: slavizacijos apybraiža [Lithuanian (Baltic) heritage in the surnames of the Białystok voivodeship in Poland: an outline of Slavicisation]. Vilnius: Mokslo ir Enciklopedijų leidybos institutas.

\section{SUMMARY}

CONTEMPORARY POLISH SURNAMES OF POSSIBLE LITHUANIAN ORIGIN ABSENT FROM THE DICTIONARY OF LITHUANIAN SURNAMES (LPŽ), ATTESTED IN THE ANTHROPONYMIC FILES OF THE INSTITUTE OF THE LITHUANIAN LANGUAGE

The aim of the article is to present the attestations of contemporary Polish surnames of Lithuanian origin which are absent from the dictionary of Lithuanian surnames ("Lietuvių pavardžių žodynas", LPŽ), excerpted from the anthroponymic index card files that have been stored in the Lithuanian Language Institute in Vilnius and continually enlarged for several decades now. The files contain data excerpted from historical sources of the 16th to 19th centuries and consist of about 200,000 index cards (the actual number of excerpted anthroponyms is lower since some recur in various sources). Due to space limitations, generally only directly attested names have been included in the article, to the exclusion of those whose relationship with the researched name can be inferred rather than considered proven. Each listed attestation of an anthroponym (probably not in all cases an already established hereditary surname) is accompanied by information concerning its location and year (or time bracket), wherever available in the card index file. Given names or other details (e.g. the role of the person mentioned in documents, such as godmother in the data excerpted from baptismal registers) have only been included occasionally, if there was some reason to do so.

Keywords: Polish surnames, surnames of Lithuanian origin, etymological and motivational surname dictionary, index card files, Institute of the Lithuanian Language 